\title{
Tingkat Pengetahuan tentang Vaginal Hygiene dan Kepuasan terhadap Penggunaan V-Cleanser Foam Berbahan Ekstrak Daun Sirih Hijau
}

\author{
Sukmawati Tansil Tan ${ }^{1}$, Yohanes Firmansyah ${ }^{1}$, Jessica Elizabeth ${ }^{1}$, Jessica Nadia Dinda
}

Fakultas Kedokteran Universitas Tarumanagara, Jakarta, Indonesia Alamat Korespondesi: yohanesfirmansyah28@gmail.com

\begin{abstract}
Abstrak
Kebiasaan membersihkan area kewanitaan yang salah dapat berdampak pada kesehatan reproduksi, sehingga setiap wanita perlu memiliki pengetahuan yang baik tentang vaginal hygiene. Pengetahuan dan sikap yang benar dalam menjaga kebersihan daerah kewanitaan akan mencegah berbagai macam penyakit reproduksi seperti keputihan yang disebabkan oleh infeksi jamur dan bakteri. Beberapa produk pembersih kewanitaan menggunakan bahan-bahan alami seperti ekstrak daun sirih hijau yang telah diteliti memiliki manfaat sebagai antibakteri dan antisepsis. Tujuan dari penelitian ini adalah untuk mengetahui tingkat pengetahuan tentang vaginal hygiene dan kepuasan terhadap penggunaan $\mathrm{V}$-Cleanser foam berbahan ekstrak daun sirih hijau. Penelitian ini menggunakan desain penelitian deskriptif berupa penggunaan $V$ Cleanser foam selama 2 minggu dengan metode pengambilan sampel consecutive non random sampling dan instrumen penelitian yang digunakan adalah kuesioner. Responden penelitian adalah wanita berusia $>18$ tahun. Dari 95 responden, didapatkan 34,7\% responden memiliki pengetahuan baik, 41,1\% responden memiliki pengetahuan cukup dan $24,2 \%$ responden memiliki pengetahuan buruk. Berdasarkan hasil tingkat kepuasan terhadap penggunaan $\mathrm{V}$-Cleanser foam berbahan ekstrak daun sirih hijau didapatkan responden yang merasa sangat puas sebesar $61 \%$ dan yang merasa puas sebesar $38,9 \%$. Simpulan pada panelitian ini adalah umumnya responden memiliki pengetahuan yang cukup dengan tingkat kepuasan pemakaian $V$ Cleanser foam dalam kategori puas.
\end{abstract}

Kata kunci: ekstrak daun sirih, kebersihan vagina

\section{Vaginal Hygiene and Satisfaction with the Use of V-Cleanser Foam Made from Green Betel Leaf Extract}

\begin{abstract}
Personal hygiene practices using vaginal hygiene product can affect women's reproductive health. Therefore, it is important to have good knowledge on vaginal hygiene in order to maintain good reproductive health. In addition, this practice may prevent various kinds of reproductive health problems caused by yeast and bacterial infection. Some of cleanser products use natural ingredients, such as green betel leaf extracts have been studied to have antibacterial properties. The aim of this research was to find out the level of knowledge on vaginal hygiene and satisfaction with the use of V-Cleanser Foam made from green betel leaf extract. This study used a descriptive design with a consecutive non-random sampling. The respondents were women over 18 years old, each was given V-Cleanser Foam made from green betel leaf extract for 2 weeks and asked to fill out questionnaire. From 95 samples, 34.7\% of respondents had good level of knowledge, 41,1\% had sufficient level of knowledge, and 24,2\% had bad level of knowledge about vaginal hygiene. According to the level of satisfaction using the V-Cleanser product, the results showed $61 \%$ of respondents were very satisfied and $38,9 \%$ were satisfied. This study concludes that respondents have sufficient knowledge on vaginal hygiene, with most of them satisfied with using V-Cleanser foam.
\end{abstract}

Keywords: green betel leaf extract, vaginal hygienenser 


\section{Pendahuluan}

Secara umum kesehatan reproduksi merujuk pada kondisi kesejahteraan fisik, mental, dan kehidupan sosial dalam segala hal yang berkaitan dengan sistem reproduksi. Termasuk hak dan kebebasan untuk bereproduksi secara aman, efektif, tepat, terjangkau, dan tidak melawan hukum. ${ }^{1-3}$ Kesehatan reproduksi di kalangan wanita merupakan masalah yang penting untuk diperhatikan. Beberapa penyakit infeksi organ reproduksi wanita adalah trikomoniasis, gonore, klamidiasis, dan sifilis. ${ }^{4,5}$

Pengetahuan tentang pentingnya reproduksi sehat belum disadari sepenuhnya oleh masyarakat. Hal ini dikarenakan kurangnya pengetahuan dan informasi di dalam masyarakat. Oleh karena itu perlu adanya kesadaran tentang pentingnya reproduksi sehat pada masyarakat. ${ }^{6,7}$

Kesehatan reproduksi adalah keadaan sejahtera fisik, mental dan sosial yang utuh, yang bebas dari penyakit, yang berkaitan dengan sistem reproduksi, termasuk fungsi dan prosesnya ${ }^{2,4,8}$ Masalah kesehatan reproduksi yang sering terjadi pada wanita antara lain keputihan, rasa gatal dalam vagina dan di sekitar bibir vagina bagian luar.,

Data penelitian tentang kesehatan reproduksi wanita, menunjukkan $75 \%$ wanita di Indonesia pernah menggunakan cairan pembersih untuk menjaga personal hygiene mereka, yang dilakukan secara rutin. Jenis pembersih yang sering digunakan adalah $45 \%$ menggunakan sabun, dan 30\% menggunakan cairan pembersih dengan berbagai merk. ${ }^{9}$

Daun sirih hijau (Piper betle L.) merupakan salah satu tanaman obat yang banyak tumbuh di Indonesia. ${ }^{10-13}$ Produk sabun pembersih vagina atau $\mathrm{V}$-Cleanser yang saat ini banyak beredar di pasaran kebanyakan mengandung bahan-bahan kimia. Bahan-bahan kimia ini dapat mengganggu keseimbangan $\mathrm{pH}$ dan flora normal vagina sehingga membuat vagina lebih kering, iritasi dan rentan terkena penyakit infeksi. Air rebusan daun sirih hijau diketahui merupakan bahan alami yang dapat digunakan untuk membersihkan area kewanitaan. Cara ini terbukti dapat merawat vagina dan menghindari keputihan sehingga daun sirih hijau dapat menjadi salah satu alternatif bahan dasar $V$ Cleanser untuk mengurangi bau dan memiliki efek samping yang lebih kecil untuk terjadinya iritasi ${ }^{14,15}$ Melihat kemampuan daun sirih hijau untuk pengobatan keputihan, maka saat ini telah diproduksi berbagai macam produk kewanitaan berbahan baku daun sirih hijau yang dapat ditemukan dalam bentuk foam, gel, dan tissue pembersih kewanitaan. ${ }^{16-18}$

Kelebihan $\mathrm{V}$-Cleanser dalam bentuk foam adalah mudah diaplikasikan pada permukaan kulit, lebih lembut, lebih hemat, dan mengurangi iritasi (mild ingredients). Ekstrak daun sirih yang terkandung dalam $\mathrm{V}$-Cleanser foam bersifat antiseptik, memiliki konsentrasi ekstrak daun sirih yang lebih tinggi, dan memiliki $\mathrm{pH}$ yang sama dengan daerah vulvovagina sehingga aman untuk digunakan sebagai pembersih daerah kewanitaan seharihari. ${ }^{19,20}$

Tujuan dilakukannya penelitian ini adalah untuk mengetahui tingkat pengetahuan tentang vaginal hygiene, dan mengukur kepuasan terhadap penggunaan $V$-Cleanser foam berbahan ekstrak daun sirih hijau, agar masyarakat lebih paham mengenai produk pembersih pada alat reproduksi.

\section{Metodologi}

Penelitian ini merupakan penelitian deskriptif dengan metode survei. Penelitian dilakukan di daerah Grogol yaitu sekitar kampus Universitas Tarumanagara pada periode September -Oktober 2019. Sampel penelitian adalah seluruh perempuan di sekitar kampus Universitas Tarumanagara yang bersedia di wawancara dan memenuhi kriteria inklusi. Teknik pengambilan sampel yang digunakan adalah total population sampling, dimana berdasarkan rumus perkiraan besar sampel dibutuhkan 94 responden (proporsi $50 \%$ dan kesalahan tipe 1 sebesar 5\%). Kriteria inklusi penelitian adalah responden dengan usia $\geq 18$ tahun serta bersedia menjadi responden dan menggunakan $V$-Cleanser foam berbahan ekstrak daun sirih selama 2 minggu. Kriteria eksklusi pada penelitian ini adalah responden yang mempunyai riwayat alergi terhadap kandungan pembersih tertentu.

Kuesioner digunakan untuk mengukur pengetahuan serta kepuasan/ pengalaman responden selama menggunakan $V$-Cleanser foam berbahan ekstrak daun sirih hijau yang digunakan selama 2 minggu. $V$-Cleanser foam berbahan ekstrak daun sirih hijau yang digunakan dalam penelitian merupakan produk 
yang sudah disertifikasi Badan Pengawas Obat dan Makanan.

Variabel dalam penelitian ini meliputi variabel bebas berupa penggunaan $V$-Cleanser foam berbahan ekstrak daun sirih hijau dan variabel tergantung berupa tingkat pengetahuan dan kepuasan responden. Skala data variabel pengetahuan merupakan skala ordinal yang terbagi atas tingkat pengetahuan baik jika hasil presentase kuesioner 76-100\%, tingkat pengetahuan cukup jika hasil presentase kuesioner 56-75\% dan tingkat pengetahun kurang jika hasil presentase kuesioner $<56 \%$. Skala data variabel kepuasan merupakan skala ordinal yang terdiri dari sangat puas, cukup puas, dan tidak puas yang bergantung pada jawaban responden. Kuesioner pengetahuan dan kepuasan responden yang digunakan dalam penelitian ini telah melalui uji validasi internal dan uji keandalan dengan nilai korelasi $(r)>0,3$ dan nilai Cronbach alpha $>0,80$.

Data hasil penelitian diolah menggunakan analisis deskriptif berupa penyajian tabel karakteristik sebaran demografi dan jawaban responden. Penelitian ini melibatkan intervensi atau pemberian produk kepada manusia atau responden. Oleh karena itu, penelitian ini mengajukan kaji etik kepada Universitas Tarumanagara Human Research Ethic Community (UTHREC) dengan nomor Kaji Etik adalah PPZ20192062

\section{Hasil}

Penelitian mengikutsertakan 95 responden dengan rata-rata umur adalah $28,37 \pm 7,75$ tahun, mayoritas memiliki pekerjaan sebagai karyawan swasta $(16,8 \%)$, serta lajang $(56,8 \%)$, seperti yang tertera pada Tabel 1 .

Tabel 3. Klasifikasi Pengetahuan 95 Responden

\begin{tabular}{lll}
\hline & Parameter & \% \\
\hline$\bullet$ & Buruk & 24,2 \\
$\bullet$ & Cukup & 41,1 \\
$\bullet$ & Baik & 34,7 \\
& & \\
\hline
\end{tabular}

Tabel 5. Klasifikasi Kepuasan 95 Responden

\begin{tabular}{|c|c|}
\hline Parameter & $\%$ \\
\hline $\begin{aligned} \text { Kepuasan } \\
$\[ \quad \text { Sangat puas } \]$ \\
\bullet \quad \text { Puas }\end{aligned}$ & $\begin{array}{c}61 \\
38,9\end{array}$ \\
\hline
\end{tabular}

Tabel 1. Karakteristik Demografi 95 Responden

\begin{tabular}{lc}
\hline Parameter & \% \\
\hline Pekerjaan & \\
Bidan & 1,1 \\
CS & 1,1 \\
Dokter & 11,5 \\
Guru & 2,1 \\
Guru PNS & 1,1 \\
Ibu Rumah Tangga & 11,5 \\
Karyawan & 2,1 \\
Karyawan Swasta & 16,8 \\
Mahasiswa/i & 14,8 \\
Penjaga Kos & 9,5 \\
Penjaga Toko & 8,4 \\
Perawat & 15,8 \\
PNS & 3,2 \\
Wiraswasta & 1,1 \\
Status Pernikahan & \\
\multicolumn{1}{c}{$\bullet \quad$ Lajang $\quad$ Menikah } & 56,8 \\
\hline
\end{tabular}

Penelitian ini mengikutsertakan 95 responden untuk menjawab kuesioner pengetahuan mengenai $V$-Cleanser yang berjumlah 10 pertanyaan. Dari 10 pertanyaan, terdapat 7 pertanyaan yang memiliki persentase benar dibawah 75 persen yaitu pertanyaan nomor 1, 3, 4, 6, 7, 9 dan 10. Seluruh responden menjawab sepuluh pertanyaan tanpa terlewat dengan rentang nilai poin benar dari 1 poin hingga 10 poin. Sebanyak $24,2 \%$ responden berpengetahuan kurang dengan hasil presentase kuesioner $<56 \%$, sebanyak $41,1 \%$ responden berpengetahuan cukup dengan hasil presentase kuesioner $56-75 \%$, serta $34,7 \%$ responden berpengetahuan baik dengan hasil presentase kuesioner 76-100\% (Tabel 2 dan 3). Distribusi jawaban 95 responden mengenai kuesioner kepuasan didominasi jawaban sangat puas untuk pertanyaan nomor $1,4,5$, dan 10 , serta dominasi jawaban puas untuk pertanyaan nomor 2, 3, 6, 7, 8, dan 9 (Tabel 4 dan 5). 
Tabel 2. Distribusi Jawaban 95 Responden Terhadap Kuesioner Pengetahuan

\begin{tabular}{|c|c|c|c|c|}
\hline \multirow[t]{2}{*}{ No } & \multirow[t]{2}{*}{ Pertanyaan } & \multirow[t]{2}{*}{$(\%)$} & \multicolumn{2}{|c|}{ Jawaban $(\%)$} \\
\hline & & & $\mathrm{S}$ & B \\
\hline \multirow[t]{4}{*}{1} & Menurut anda vaginal cleanser adalah? & & 27,4 & 72,6 \\
\hline & a. Produk pembersih kulit & 25,3 & & \\
\hline & b. Produk pemutih & 2,1 & & \\
\hline & c. Produk pembersih area kewanitaan & 72,6 & & \\
\hline \multirow[t]{4}{*}{2} & Yang bukan merupakan jenis $V$-Cleanser adalah? & & 20 & 80 \\
\hline & a. Gel & 9,5 & & \\
\hline & b. Foam & 10,5 & & \\
\hline & c. Salap & 80 & & \\
\hline \multirow[t]{4}{*}{3} & Golongan usia manakah yang dapat menggunakan V-Cleanser? & & 36,8 & 63,2 \\
\hline & - Bayi dan anak - anak & 1,1 & & \\
\hline & - Remaja perempuan dan dewasa & 63,2 & & \\
\hline & - Segala usia & 35,7 & & \\
\hline \multirow[t]{4}{*}{4} & Dalam sehari, berapa kali sebaiknya $V$-Cleanser digunakan? & & 46,3 & 53,7 \\
\hline & - $0-1$ kali & 20 & & \\
\hline & - $\quad 1-2$ kali & 53,7 & & \\
\hline & - Setiap selesai buang air kecil & 26,3 & & \\
\hline \multirow[t]{4}{*}{5} & $\begin{array}{l}\text { Berikut adalah upaya yang sehari-hari dapat dilakukan untuk menjaga } \\
\text { daerah kewanitaan seperti? }\end{array}$ & & 17,9 & 82,1 \\
\hline & - Menggunakan panty liners setiap hari & 1,1 & & \\
\hline & $\begin{array}{l}\text { - Membersihkan daerah kewanitaan dengan arah dari belakang ke } \\
\text { depan tiap selesai BAK }\end{array}$ & 16,8 & & \\
\hline & $\begin{array}{l}\text { - Mengeringkan daerah kewanitaan dengan handuk bersih atau } \\
\text { tissue tiap selesai BAK }\end{array}$ & 82,1 & & \\
\hline \multirow[t]{4}{*}{6} & $\begin{array}{l}\text { Menurut anda berapa kali sehari sebaiknya mengganti celana dalam? } \\
\text { - } 1 \mathrm{x} \text { sehari }\end{array}$ & & 38,9 & 61,1 \\
\hline & - $2 x$ sehari & 7,4 & & \\
\hline & - Segera diganti saat celana dalam terkena kotoran atau basah & 31,5 & & \\
\hline & & 61,1 & & \\
\hline \multirow[t]{4}{*}{7} & $\begin{array}{l}\text { Menurut anda apakah bahaya yang dapat terjadi jika tidak } \\
\text { memperhatikan daerah kewanitaan? }\end{array}$ & & 25,3 & 74,7 \\
\hline & - Keputihan & 13,7 & & \\
\hline & - $\quad$ Kanker serviks & 11,6 & & \\
\hline & - Semua benar & 74,7 & & \\
\hline \multirow[t]{4}{*}{8} & Faktor apa saja yang memengaruhi kebersihan daerah kewanitaan? & & 18,9 & 81,1 \\
\hline & - Produk pembersih daerah kewanitaan & 8,4 & & \\
\hline & - Semua benar & 10,5 & & \\
\hline & & 81,1 & & \\
\hline \multirow[t]{4}{*}{9} & $\begin{array}{l}\text { Bagaimanakah cara penggunaan pembersih daerah kewanitaan yang } \\
\text { baik? }\end{array}$ & & 68,4 & 31,6 \\
\hline & - Membersihkan bagian luar kelamin saja & 31,5 & & \\
\hline & - Membersihkan bagian dalam (vagina) saja & 7,4 & & \\
\hline & - Membersihkan bagian luar sampai bagian dalam vagina & 61,1 & & \\
\hline \multirow[t]{4}{*}{10} & $\begin{array}{l}\text { Mengapa ekstrak daun sirih dapat digunakan untuk pembersih daerah } \\
\text { kewanitaan? }\end{array}$ & & 32,6 & 66,4 \\
\hline & - Bahannya alami & 29,5 & & \\
\hline & - $\quad$ Efek samping minimal & 3,2 & & \\
\hline & - Semua benar & 67,3 & & \\
\hline
\end{tabular}

Keterangan: S (salah), B (benar) 
Tabel 4. Distribusi Jawaban 95 Responden Terhadap Kuesioner Kepuasan

\begin{tabular}{|c|c|c|c|c|c|c|}
\hline \multirow[t]{2}{*}{ No } & \multirow[t]{2}{*}{ Pertanyaan } & \multicolumn{5}{|c|}{ Jawaban respoden $(\%)$} \\
\hline & & $\begin{array}{l}\text { Sangat tidak } \\
\text { puas }\end{array}$ & Tidak puas & Cukup puas & Puas & $\begin{array}{c}\text { Sangat } \\
\text { puas }\end{array}$ \\
\hline 1 & $\begin{array}{l}\text { Bagimana menurut Anda sediaan } V \text { - } \\
\text { Cleanser dalam bentuk foam lebih baik } \\
\text { daripada bentuk pembersih lainnya? }\end{array}$ & 0 & 0 & 10,5 & 36,8 & 52,6 \\
\hline 2 & $\begin{array}{l}\text { Bagaimana menurut Anda sediaan } V \text { - } \\
\text { Cleanser dalam bentuk foam lebih } \\
\text { hemat? }\end{array}$ & 0 & 0 & 22,1 & 44,2 & 33,7 \\
\hline 3 & $\begin{array}{l}\text { Bagaimana menurut Anda sediaan } V \text { - } \\
\text { Cleanser dalam bentuk foam lebih } \\
\text { lembut? }\end{array}$ & 0 & 0 & 17,9 & 45,4 & 36,8 \\
\hline 4 & $\begin{array}{l}\text { Bagaimana menurut Anda kelebihan } \\
\text { sediaan } V \text {-Cleanser dalam bentuk foam } \\
\text { yang tidak mengiritasi daerah } \\
\text { kewanitaan? }\end{array}$ & 0 & 0 & 18,9 & 38,9 & 42,1 \\
\hline 5 & $\begin{array}{l}\text { Bagaimana wangi yang Anda rasakan } \\
\text { setelah memakai V-Cleanser foam } \\
\text { berbahan ekstrak daun sirih? }\end{array}$ & 0 & 0 & 20 & 36,8 & 43,2 \\
\hline 6 & $\begin{array}{l}\text { Bagaimana manfaat } V \text {-Cleanser foam } \\
\text { berbahan ekstrak daun sirih dalam } \\
\text { membersihkan area kewanitaan Anda? }\end{array}$ & 0 & 0 & 23,2 & 42,1 & 34,7 \\
\hline 7 & $\begin{array}{l}\text { Bagaimana manfaat } V \text {-Cleanser foam } \\
\text { berbahan ekstrak daun sirih dalam } \\
\text { mengurangi gatal-gatal sekitar } \\
\text { kemaluan? }\end{array}$ & 0 & 0 & 29,5 & 40 & 30,5 \\
\hline 8 & $\begin{array}{l}\text { Bagaimana manfaat } V \text {-Cleanser foam } \\
\text { berbahan ekstrak daun sirih dalam } \\
\text { mengurangi keputihan yang berbau? }\end{array}$ & 0 & 0 & 17,9 & 48,4 & 33,7 \\
\hline 9 & $\begin{array}{l}\text { Bagaimana manfaat 'rasa keset' yang } \\
\text { dirasakan pada area kewanitaan Anda? }\end{array}$ & 0 & 0 & 11,6 & 47,4 & 41,1 \\
\hline 10 & $\begin{array}{l}\text { Bagaimana manfaat penggunaan } V \text { - } \\
\text { Cleanser foam berbahan ekstrak daun } \\
\text { sirih dalam mencegah masalah-masalah } \\
\text { di sekitar area kewanitaan? }\end{array}$ & 0 & 0 & 16,8 & 40 & 43,2 \\
\hline
\end{tabular}

\section{Pembahasan}

Ekstrak daun sirih hijau (Piper betle) dan ekstrak daun sirih merah (Piper crocatum) masing-masing telah terbukti memiliki efek antimikroba terhadap Candida albicans, inilah alasan mengapa daun sirih sering digunakan sebagai pembersih vagina. Penelitian dari Kurniawati (2014) mengungkapkan kombinasi $P$. betle dan $P$. crocatum memiliki aktivitas antimikroba yang tinggi. ${ }^{21}$ Hasil ini dibuktikan dengan tidak adanya pertumbuhan koloni setelah perawatan. Penelitian Kurniawati dkk juga mendapatkan bahwa kemampuan antijamur dari daun sirih hijau lebih tinggi dibandingkan dengan daun sirih merah. ${ }^{21}$ Penelitian dari Ana Mardiyaningsih dkk (2018) memaparkan terapi intervensi menggunakan pengujian minyak atsiri kombinasi lengkuas merah, kayu manis dan daun sirih hijau mampu menghambat pertumbuhan jamur Candida albicans lebih tinggi dibandingkan dengan obat nystatin. ${ }^{22}$ Hasil penelitian ini menjadi alasan utama peneliti menggunakan ekstrak daun sirih hijau sebagai bahan dasar V-Cleanser.

Keputihan patologis adalah keputihan yang terjadi karena infeksi bakteri dan jamur di mana cairan yang keluar banyak dan terus-menerus dari vagina dan warna cairan tidak jernih atau putih atau kuning atau kehijauan. Penelitian dari Sri Wulan (2019) mengungkapkan bahwa terdapat efek positif dari pemberian rebusan daun sirih merah terhadap keputihan patologis pada wanita muda di SMA Merbau 1. Peneliti menyarankan agar petugas kesehatan dapat 
memperkenalkan lebih banyak tentang manfaat daun sirih kepada masyarakat, terutama wanita, sehingga masyarakat memiliki tingkat pengetahuan yang lebih terhadap vaginal hygiene dan lebih percaya diri dalam menggunakan perawatan non-farmakologis seperti $V$-Cleanser. ${ }^{19}$

Pengetahuan masyarakat terhadap kebersihan alat genitalia eksterna berhubungan dengan sikap serta perilaku masyarakat dalam menjalankannya. Hal ini terlihat dari penelitian Widya Nurlita (2014) yang memaparkan bahwa dari 39 responden terdapat $48,7 \%$ orang memiliki pengetahuan cukup dan sebanyak $43,6 \%$ orang memiliki pengetahuan yang baik. Dari tingkat pengetahuan tersebut, terdapat $17,9 \%$ siswi yang memiliki perilaku yang cukup, sementara $82,1 \%$ siswi memiliki perilaku yang baik dalam menjaga kebersihan organ genetalia eksterna. ${ }^{23}$

Beberapa penelitian melaporkan tingkat pengetahuan responden yang rendah tentang kebersihan genitalia eksterna. Penelitian dari Ayuningtyas Donatila Novrinta (2011) mengungkapkan sebanyak $82,8 \%$ responden memiliki pengetahuan mengenai cara menjaga kebersihan genitalia eksterna yang buruk. Hasil uji statistik menunjukan terdapat hubungan antara pengetahuan mengenai cara menjaga kebersihan genitalia eksterna dengan kejadian keputihan pada siswi SMA Negeri 4 Semarang $(\mathrm{p}=0,027) \cdot{ }^{24}$ Penelitian lain dari Tetti Solehati dan rekan (2019) memperlihatkan bahwa walaupun sebagian besar $(76 \%)$ responden memiliki tingkat pengetahuan yang baik, namun didapati 53,9\% mempunyai sikap yang buruk terhadap kebersihan genitalia eksterna. ${ }^{25}$ Dengan pertimbangan ini, penulis menganggap penting untuk dilakukan intervensi guna meningkatkan pengetahuan masyarakat mengenai kebersihan alat genitalia, terutama dengan $\mathrm{V}$-Cleanser yang berbahan dasar alami seperti ekstrak daun sirih hijau.

Pengetahuan kebersihan genitalia eksterna merupakan faktor penting yang dapat meningkatkan kebersihan alat genitalia wanita. Penelitian yang dilakukan oleh Wahyu Amelia (2018) menjelaskan pentingnya pengetahuan masyarakat mengenai kebersihan genitalia eksterna dikarenakan pengetahuan merupakan faktor yang sangat berperan terhadap angka kejadian keputihan dan keluhan seputar genitalia ( $p$-value : 0,013$).{ }^{26}$
Penelitian ini juga mengungkapkan bahwa penggunaan $V$-cleanser dalam bentuk foam menimbulkan rasa nyaman dan efek positif yang lebih banyak bila dibandingkan dengan $V$ cleanser jenis lain. Adapun kelebihan dari $v$ cleanser dalam bentuk foam adalah lebih hemat, lebih nyaman, dan lebih lembut. Tidak ada penelitian lain yang mengungkapkan kelebihan bentuk foam bila dibandingkan $V$ cleanser sediaan lain

\section{Simpulan}

Masih terdapat $24,2 \%$ responden yang memiliki pengetahuan buruk sehingga masih diperlukan intervensi lebih lagi untuk meningkatkan tingkat pengetahuan masyarakat mengenai kebersihan reproduksi. Tingkat kepuasan terhadap penggunaan $V$-Cleanser foam berbahan ekstrak daun sirih hijau didapatkan responden yang merasa sangat puas sebesar $61 \%$ dan yang merasa puas sebesar $38,9 \%$.

\section{Ucapan Terima Kasih}

Terimakasih kami haturkan kepada PT. Sukma Skin Treatment dan Universitas Tarumanagara terhadap perizinan serta pendanaan yang diberikan pada penelitian ini. Tidak lupa kami juga berterimakasih kepada 2 dokter yang berperan sebagai asisten penelitian pada penelitian ini yaitu dr. Vini Firgianti dan dr. Intan Suherman.

\section{Daftar Pustaka}

1. Kementerian Kesehatan RI. Infodatin reproduksi remaja-Ed.Pdf. Situasi Kesehatan Reproduksi Remaja. 2017.

2. Djama NT. Kesehatan reproduksi remaja. J Kesehat Poltekkes Ternate. 2017;10(1)

3. Fatkhiyah N, Masturoh M, Atmoko D. Edukasi kesehatan reproduksi remaja. J Abdimas Mahakam. 2020;4:84-9.

4. Manuaba I. Memahami kesehatan reproduksi wanita. Jakarta: Arcan. 2010.

5. Gilly A. Buku ajar kesehatan reproduksi wanita. EGC. 2010.

6. Manuaba. Ilmu kebidanan, penyakit kandungan, dan KB. Ilmu Kebidanan, Penyakit, Kandungan, dan KB. 2012.

7. Manuaba, IBG. Penyakit kandungan dan KB untuk pendidikan bidan. Dalam: Ilmu 
Kebidanan. 2014.

8. Pinem S. Kesehatan reproduksi dan kontrasepsi. Jakarta: Trans Info Media. 2014.

9. Moeljatno. Khasiat dan manfaat daun sirih obat mujarab dari masa ke masa, Agromedia Pustaka,. Jakarta. 2003.

10. Syahrinastiti TA, Djamal A, Irawati L. Perbedaan daya hambat ekstrak daun sirih hijau (Piper betle L.) dan daun sirih merah (Piper crocatum Ruiz \& Pav ) terhadap pertumbuhan Escherichia coli. J Kesehat Andalas. 2015;4(2):421-4.

11. Kursia S, Lebang JS, Taebe B, Burhan A, Rahim WO., Nursamsiar. Uji aktivitas antibakteri ekstrak etilasetat daun sirih hijau (Piper betle L.) terhadap bakteri Staphylococcus epidermidis. Indones $\mathbf{J}$ Pharm Sci Technol. 2016;3(2):72-7.

12. Gunawan A, Eriawati E, Zuraidah Z. Pengaruh pemberian ekstrak daun sirih (Piper sp.) terhadap pertumbuhan jamur Candida albicans. Pros Biot. 2018;2(1):368-76.

13. Effa E, Puetri NR. Pengaruh pemberian ekstrak daun sirih (Piper betle 1.) terhadap pertumbuhan Staphylococcus aureus isolat dari penderita faringitis. Sel. 2015; 2(2):57-65.

14. Astuti ika yuni, Hartati D, Aminati A. Peningkatan aktivitas antijamur Candida albicans salep minyak atsiri daun sirih (Piper betle Linn.) melalui pembentukan kompleks inklusi dengan $\beta$-siklodekstrin. Maj Obat Tradis. 2010;15 (3):94-9.

15. Zuraidah. Pengujian ekstrak daun sirih (Piper Sp.) yang digunakan oleh para wanita di Gampong Dayah Bubue, Pidie dalam mengatasi kandidiasis akibat cendawan Candida albican. Gend Equal Int J Child Gend Stud. 2015;1(2):109-18.

16. Putriningrum R, Khoiriyah A. Kajian efek sinergistik anti jmur esktrak biji pinang (Arecacathechu L.) dan daun sirih merah (Piper betle L.) untuk pencegahan kandididasis vulvovaginal. J KesMaDaSka. 2014;5(1):42-9.
17. Manurung YD. Perawatan Postpartum Menurut Perspektif Budaya Jawa. Fak Keperawatan USU. 2010.

18. Tee SM. Uji daya hambat suppositoria vagina ekstrak daun sirih hijau (Piper betle L.) terhadap Candida albicans. J Insa Farm Indones. 2018;1(1):122-9.

19. Wulan S. Pengaruh pemberian rebusan daun sirih merah terhadap keputihan patologis pada remaja putri. J Penelit Kebidanan Kespro. 2019;1(2):19-22.

20. Sari $N$ et al. Efek rebusan daun sirih untuk mengurangi keputihan pada wanita. J Skala Husada. 2016; 2(1):79-89.

21. Kurniawati D. Aktivitas antimikroba kombinasi rebusan daun sirih hijau (Piper betle) dan daun sirih merah (Piper crocatum) terhadap Candida albicans. J Akad Biol. 2014;3(1):55-61.

22. Ana Mardiyaningsih RA. Potensi minyak atsiri ratus vagina dengan kombinasi lengkuas merah (Alpinia purpurata $\mathrm{K}$. Schum), kayu manis (Cinnamomum burmanii blume) dan daun sirih hijau ( Piper betle 1) sebagai antifungi terhadap Candida albicans secara in vitro. Med Respati J Ilmu Kesehat. 2018;13(4):4357.

23. Nurlita W. Gambaran tingkat pengetahuan dan perilaku menjaga kebersihan organ genetalia eksterna ada siswi MI Pembagunan. Mark Sci. 2014.

24. Novrinta AD. Hubungan antara pengetahuan dan perilaku menjaga kebersihan genetalia eksterna dengan kejadian keputihan pada siswi SMA Negeri 4 Semarang. FK Undip. 2011.

25. Solehati T, Mambang Sari CW, Rohimah I. Pengetahuan, sikap dan tindakan siswi sekolah dasar terkait genitalia hygiene. J Keperawatan Muhammadiyah. 2019;4(1):117-26.

26. Amelia W. Genitalia dengan kejadian keputihan pada mahasiswi tingkat II STIKES AL- Ma'arif Baturaja. J Kesehat. $2018 ; 8(16)$. 